\title{
PERLINDUNGAN HUKUM BAGI JABATAN NOTARIS BERDASARKAN PASAL 66 UUJN SETELAH LAHIRNYA PUTUSAN MAHKAMAH KONSTITUSI REPUBLIK INDONESIA NOMOR: 49/PUU-X/2012
}

Oleh

\author{
Putu Wisnu Pradnyan Mulya ML*, (I Gusti Ngurah Wairocana)**, (Ida Bagus \\ Agung Putra Santika)*** \\ Program Magister Kenotariatan Universitas Udayana \\ Email : pradnyanmulya@gmail.com
}

\begin{abstract}
Notary Supervisory Regional Assembly (MPD) is an institution that is based upon the provisions of Article 66 and Article70 (a) of Law No. 30 of 2004 Regarding Notary. The presence of MPD in the practice of providing protection for the notary public to call as a witness to the deed is made for the purpose of investigations or proceedings in a civil or criminal case. Based MKRI's Decision Number 49/PUU-X-2012 dated May 28, 2013, authorized the MPD as a protective institution notary office to be reduced, so that each call-related notary deed made in the examination as a witness or as a defendant/suspect by police, prosecutors and following a court decision photo copy minute deed or notarial protocol in storage no longer require the approval ofthe MPD. Issues arising under the MKRI'S decision are the lack of legal protection forthe notary, but notary publicis an officer who makes authentic act that has legal force and position it perfectly guaranteed by law. Based on the problems, can be formulated in concerns about how the form of legal protection for the office of notary public in the event ofa notary as a witness by calling the police or the courts after the birth of the MKRI Judgment and Decision MKRI whether it also resulted in the provision of Article 70 (a) does not need to be implemented by the MPD in relation to the result of calling the notary deed is made.
\end{abstract}

Keywords: Legal Protection, Incumbency, Notary, Decision, the Constitutional Court, MPD

* Mahasiswa Program Studi Magister Kenotariatan T.A. 2012

**Pembimbing I

***Pembimbing II

\section{PENDAHULUAN}

Secara umum setiap negara yang menganut paham negara hukum memberlakukan (3) tiga prinsip dasar, yakni supermasi hukum (supremacy of law), kesetaraan di hadapan hukum (equality before the law), dan penegakan hukum dengan cara tidak bertentangan dengan hukum (due process of law), juga prinsip penting dalam negara hukum adalah perlindungan yang sama (equal protection) atau persamaan dalam hukum (equality before the law).

Kemudian (due process of law) dalam arti substansif adalah suatu persyaratan yuridis yang menyatakan bahwa pembuatan suatu peraturan hukum tidak boleh berisikan hal-hal yang dapat mengakibatkan perlakuan manusia secara tidak adil, tidak logis dan sewenang-wenang.

Sejalan dengan paparan tentang due process of law seperti di atas dan dalam kaitannya dengan penulisan tesis ini adalah keberadaan atau eksistensi suatu lembaga yang bernama Majelis Pengawas Notaris Daerah (MPD). Lembaga yang lahir berdasarkan pada ketentuan Pasal 66 dan Pasal 70 huruf (a)Undang-Undang Nomor 30 tahun 2004 Tentang Jabatan Notaris (UUJN).

Berdasarkan pada ketentuanketentuandi atas, MPD diberi wewenang oleh negara untuk menilai atau mengukur tindakan notaris dalam membuat akta yang dimintakan kepadanya untuk dibuat, sehingga lahir sebuah akta notaris/notariil 
sebagai akta otentik (yang berkedudukan sebagai peraturan hukum bagi para pihak yang membuatnya vide Pasal 1313

KUHPerdata), tidak mengandung/berisikan hal-hal yang mengakibatkan perlakuan terhadap manusia (para pihak dalam akta) secara tidak adil, tidak logis dan sewenang-wenang.

MPD mempunyai wewenang khusus yang tidak dipunyai oleh MPW dan MPP, yaitu sebagaimana diatur di dalam pasal 66 UUJN. Bahwa MPD berwenang untuk memeriksa notaris sehubungan dengan permintaan penyidik, penuntut umum atau hakim untuk mengambil fotokopi minuta atau surat-surat lainnya yang dilekatkan pada minuta atau dalam protokol notaris dalam penyimpanan notaris, juga pemangilan notaris yang berkaitan dengan akta yang dibuatnya atau dalam protokol notaris yang berada dalam penyimpanan notaris.

Keharusan untuk memperoleh persetujuan MPD sebagaimana ketentuan Pasal 66 dan Pasal 70 huruf (a) UUJN di atas, selain untuk memenuhi syarat normatif pemanggilan notaris juga dengan tujuan agar segala hal yang disidik atau dipersalahkan kepada notaris berikut produk hukumnya terlebih dahulu dapat penilaian tentang benar atau salah suatu tindakan notaris dan aktanya. Atau apakah prosedur pembuatan akta dan akta dimaksud lahir dengan telah atau tidak sesuai dengan ketentuan dalam UUJN maupun ketentuan-ketentuan lain, seperti Kode Etik Notaris dalam kaitannya dengan pelaksanaan tugas jabatan atau dibuatnya sebuah akta otentik oleh notaris. Ketika MPD tidak mengabulkan permintaan/ permohonan memenuhi panggilan penyidik, penuntut umum, atau hakim dengan alasan notaris yang bersangkutan dalam membuat akta telah sesuai dengan prosedur pembuatan akta yang benar berdasarkan UUJN, berarti notaris yang bersangkutan dalam menjalankan tugasnya membuat suatu akta otentik telah sesuai dengan kaedah-kaedah atau norma-norma hukum dibuatnya suatu akta otentik.

Kehadiran MPD dengan kewenangan seperti tersebut ditujukan untuk memberi perlindungan hukum terhadap jabatan notaris yang diberi tugas dan wewenang menyediakan alat bukti (tertulis) sesuai dengan sistem hukum pembuktian di Indonesia secara langsung atau tidak langsung juga ditujukan untuk memberi perlindungan hukum kepada masyarakat luas dan khususnya bagi pengguna jasa notaris dalam bentuk tercapainya kepastian hukum dalam akta yang dibuat notaris.

Tujuan mulia MPD sebagai lembaga yang dapat memberi perlindungan hukum sesuai dengan makna prinsip atau konsepsi due process of law bagi jabatan notaris selama ini memang telah berjalan dan terlaksana sekalipun tidak sempurna. Akan tetapi keberadaan dan eksistentinya tersebut kemudian berakhir, akibat dilakukan pengujian konstitusional (Judicial Review) oleh Mahkamah Konstitusi Republik 
Indonesia (MKRI), terhadap ketentuan Pasal 66 Ayat 1 UUJN.

Sebab berdasarkan Putusan MKRI Nomor 49/PUU-X-2012 tertanggal 28 Mei 2013 yang dalam amar putusannya memutuskan bahwa :

1. Mengabulkan permohonan Pemohon untuk seluruhnya:

1.1 Menyatakan frasa "dengan persetujuan Majelis Pengawas Daerah" dalam Pasal 66 ayat (1) Undang-Undang Nomor 30 Tahun 2004 tentang Jabatan Notaris (Lembaran Negara Republik Indonesia Tahun 2004 Nomor 117 , Tambahan Lembaran Negara Republik Indonesia Nomor 4432) bertentangan dengan UndangUndang Dasar Negara Republik Indonesia Tahun 1945;

1.2 Menyatakan frasa "dengan persetujuan Majelis Pengawas Daerah" dalam Pasal 66 ayat (1) Undang-Undang Nomor 30 Tahun 2004 tentang Jabatan Notaris (Lembaran Negara Republik Indonesia Tahun 2004 Nomor 117, Tambahan Lembaran Negara Republik Indonesia Nomor 4432) tidak mempunyai kekuatan hukum mengikat;

2. Memerintahkan pemuatan putusan ini dalam Berita Negara Republik Indonesia sebagaimana mestinya;

Wewenang MPD sebagai lembaga pelindung jabatan notaris menjadi berkurang kalau tidak mau dikatakan sebagai berakhir. Karena berdasarkan pada Putusan MKRI di atas maka setiap pemanggilan notaris yang berkaitan dengan akta yang dibuatnya dalam pemeriksaan sebagai saksi ataupun sebagai terdakwa/tersangka oleh kepolisian, kejaksaan dan pengadilan berikut pengambilan fotokopi minuta akta atau protokol notaris dalam penyimpanannya tidak lagi memerlukan persetujuan MPD.

Hal tersebut melahirkan konsekuensi yuridis bahwa, dalam praktek pemanggilan notaris guna kepentingan penyidikan oleh kepolisian maupun persidangan oleh pengadilan, polisi maupun hakim tidak lagi memerlukan persetujuan MPD atau dapat langsung memerintahkan notaris sebagai saksi atas akta yang dibuatnya.

Secara yuridis, putusan MKRI tersebut telah meniadakan dan menjadikan tidak berlaku lagi anak kalimat “..., dengan persetujuan Majelis Pengawas Daerah..." dalam Pasal 66 UUJN. Sehingga hal tersebut secara langsung melahirkan konsekuensi terhadap perlindungan hukum bagi jabatan notaris itu sendiri, sehingga apa yang menjadi tujuan dibuat/dirumuskannya sebagai sebuah cita-cita bagi perlindungan jabatan notaris melalui UUJN menjadi sirna.

Di sisi lain, jabatan notaris bukanlah sebuah pekerjaan akan tetapi merupakan profesi. Dengan demikian, notaris adalah sebuah profesi yang diberi wewenang dan tugas membuat atau menyediakan alat bukti tertulis bagi negara (sistem hukum pembuktian) manakala negara (pengadilan) membutuhkan hal tersebut dalam penyelesaikan perkara yang dimohonkan kepadanya oleh warga negara. 
Oleh karena itu memberi jaminan kepastian hukum berupa perlindungan hukum bagi jabatan notaris mutlak diperlukan, terutama perlindungan hukum dari orang-orang yang memang dengan sengaja menggunakan akta notaris/notariil sebagai alat untuk merugikan hak dan kepentingan hukum orang lain atau yang lasimnya disebut dengan mengkriminalisasi akta notaris. Berdasarkan pada latar belakang masalah di atas, makadapat dirumuskan rumusan masalah sebagai berikut :

1. Bagaimanakah bentuk perlindungan hukum bagi jabatan notaris dalam hal terjadinya pemanggilan notaris sebagai saksi oleh kepolisian maupun pengadilan setelah lahirnya Putusan MKRI Nomor 49/PUU-X/2012?

2. Apakah Putusan MKRI Nomor 49/PUU$\mathrm{X} / 2012$ juga mengakibatkan ketentuan Pasal 70 huruf (a) tidak perlu dilaksanakan oleh MPD dalam kaitannya dengan pemanggilan notaris akibat dari akta yang dibuatnya ?

\section{LANDASAN TEORITIS}

Setiap penelitian selalu harus disertai dengan pemikiran-pemikiran teoritis, oleh karena ada hubungan timbal balik yang erat antara teori dengan kegiatan pengumpulan dan pengolahan data, analisa serta konstruksi data. Dalam penelitian ini, adapun teori yang dijadikan pisau analisi adalah :

1. Teori Keberlakuan Hukum

Keberlakuan hukum menurut Meuwissen harus dibedakan antara keberlakuan antara keberlakuan idiil dan keberlakuan normatif ${ }^{1}$. Keberlakuan idiil berkenaan dengan keberlakuan yang dipretensikan atau keberlakuan umum, misalnya putusan-putusan kefilsafatan, jadi berkenaan dngan kemungkinan untuk membenarkan atau melegitimasi putusan-putusan tertentu secara masuk akal (rasional), sedangkan keberlakuan normatif berati bahwa cara berada kaidah-kaidah dari hukum dan etika maksudnya bahwa hukum empirik ada misalnya gejalagejala tertentu yang diamati, seperti prilaku-prilaku manusia, dokumendokumen, perundang-undangan, vonis-vonis yang diidentifikasikan sebagai hukum.

2. Teori perlindungan Hukum

Salah satu sifat sekaligus tujuan hukum, adalah memberikan perlindungan/pengayoman kepada masyarakat.Pada dasarnya manusia selalu memerlukan keadilan, kebenaran dan hukum karena hal tersebut adalah nilai dan kebutuhan asasi bagi masyarakat beradab. ${ }^{2}$

3. Teori kepastian hukum

Ada empat hal yang berhubungan dengan makna kepastian hukum : pertama, bahwa hukum itu positif artinya bahwa ia adalah perundangundangan (gesetzkiches recht), kedua hukum itu didasarkan pada fakta (Tatsachen), bukan suatu rumusan tentang penilaian yang nanti akan dilakukan oleh hakim, seperti

${ }^{1}$ Meuwissen, 2007, Tentang Pengembanan Hukum, Ilmu Hukum, Teori Hukum dan Filsafat Hukum, alih bahasa B. Arieff Sidharta, Refika Aditama, Bandung, hal. 47.

${ }^{2}$ Hadjon dkk, 2002, Pengantar Administrasi Negara, Penerbit Gajah Mada University, Yogyakarta, hal. 62 
kemauan baik, kesopanan, ketiga, bahwa fakta itu harus dirumuskan dengan cara yang jelas sehingga menghindari kekeliruan dalam pemaknaan, disamping juga mudah dijalankan, kemepat,

hukum positif itu tidak boleh sering diubah. ${ }^{3}$

1. Konsep Perlindungan Hukum

Berdasar pada UUD 1945 Pasal 1 ayat 3 yang berbunyi bahwa Indonesia adalah negara hukum. Sehingga dengan sendirinya termaktub bahwa perlindungan hukum menjadi unsur esensial serta menjadi konsekuensi dalam negara hukum. Perlindungan hukum memberikan pengayoman kepada setiap warga negara yang merasa hak asasi manusianya dirugikan oleh orang lain, sehingga setiap warga negara dapat menikmati segenap haknya yang diberikan oleh hukum ${ }^{4}$.

2. Konsep Jabatan Notaris

$$
\text { Dalam Pasal } 1 \text { ayat (1) UUJN }
$$
dinyatakan, "Notaris adalah pejabat umum yang berwenang untuk membuat akta otentik dan kewenangan lainnya sebagaimana dimaksud dalam Undang-Undang ini",5. Pejabat umum merupakan terjemahan dari istilah Openbare Amtbtenaren yang berasal dari Peraturan Jabatan Notaris (selanjutnya disebut PJN) dan KUHPerdata. Openbare Amtbtenaren adalah pejabat yang mempunyai tugas yang bertalian dengan kepentingan masyarakat, sehingga openbare amtbtenaren

3 Achmad Ali, 2009, Menguak Teori (Legal Theory) dan Teori peradilan (Judicial Prudence) Termasuk Interprestasi UndangUndang( Legisprudence), Prenada Media Group, Jakarta, hal. 292.

${ }^{4}$ Satjipto Raharjo, 1993, Penyelenggaraan keadilan dalam masyarakat yang sedang berubah, jurnal masalah hukum

5 (diunduh tanggal 1 september 2014), available from: http://www.jimlyschool.com/read/analisis/384/n otaris-openbare-amtbtenaren-syafran-sofyan/ diartikan sebagai pejabat yang diserahi tugas untuk membuat akta otetik yang melayani kepentingan masyarakat, dan kualifikasi seperti itu diberikan kepada notaris

\section{PEMBAHASAN}

1. Pengertian dan Dasar Hukum Jabatan Notaris

Berangkat dari Pasal 1 angka 1 Undang-undang Nomor 30 Tahun 2004, notaris adalah pejabat umum yang berwenang untuk membuat akta otentik dan kewenangan lainnya yang disebutkan di dalam undang-undang ini. Definisi yang diberikan Undangundang Nomor 30 tahun 2004 terperinci pada tugas dan wewenang notaris sebagai pejabat umum yang berwewenang untuk membuat akat otentik serta kewenangan serta hal yang diharuskan oleh peraturan perundang-undangan.

Seseorang agar dapat diangkat menjadi seorang notaris harus memenuhi persyaratan tertentu yang mana persyaratan tersebut mutlak harus di penuhi. Hal yang mana dimaksud diatas tersebut diatur dalam Pasal 3 Undang-undang Nomor 30 Tahun 2004 :

a. Warga Negara Indonesia

b. Bertakwa kepada Tuhan Yang Maha Esa

c. Berumur paling sedikit 27 (dua puluh tujuh) tahun

d. Sehat jasmani dan rohani

e. Berijazah sarjana hukum dan lulusan jenjang strata dua kenotariatan;

f. Telah menjalani magang atau nyata-nyata telah bekerja sebagai karyawan Notaris dalam waktu 12 (duabelas) bulan berturutturut pada kantor Notaris atas prakarsa 
sendiri atau atas rekomendasi Organisasi

Notaris setelah lulus strata dua kenotariatan;

g. Tidak berstatus sebagai pegawai negeri, pejabat Negara, advokad atau tidak sedang memangku jabatan lain yang oleh undangundang dilarang untuk dirangkap dengan jabatan Notaris.

\section{Tugas dan Wewenang}

Notaris merupakan perpanjangan tangan dari pemerintah dalam hal ini negara, di mana negara telah memberikan kepercayaan kepada notaris untuk menjalankan sebagian urusan atau tugas negara, khususnya dalam bidang hukum perdata.

Keberadaan notaris menjawab kebutuhan masyarakat akan bantuan hukum yang netral dan berimbang sehingga melindungi kepentingan hukum masyarakat.Selain itu, notaris diharapkan dapat memberikan pelayanan hukum kepada masyarakat serta memberikan penyuluhan hukum, khususnya dalam pembuatan akta sehingga masyarakat akan mendapatkan perlindungan hukum dan kepastian hukum, sehubungan dengan semakin meningkatnya proses pembangunan sehingga meningkat pula kebutuhan hukum dalam masyarakat ${ }^{6}$.

Adapun kewenangan notaris sebagaimana diatur dalam pasal 15 ayat 2 undang-undang nomor 30 tahun 2004 tentang jabatan notaris adalah sebagai berikut :

1. Mengesahkan tanda tangan dan menetapkan kepastian tanggal surat di

${ }^{6}$ Santia Dewi, R.M. Fauwas Diradja, 2011, Panduan Teori dan Praktik Notaris, Yogyakarta, Penerbit Pustaka Yustisia, hal. 8. bawah tangan dengan mendaftar dalam buku khusus

2. Membukukan surat-surat di bawah tangan dengan mendaftar dalam buku khusus

3. Membuat kopi dari asli surat-surat dibawah tangan berupa salinan yang memuat uraian sebagaimana ditulis dan digambarkan dalam surat yang bersangkutan

4. Melakukan pengesahan kecocokan fotokopi dengan surat aslinya

5. Memberikan penyuluhan hukum dalam pembuatan akta

6. Membuat akta yang berkaitan dengan pertanahan, atau

7. Membuat akta risalah lelang

\section{Tanggung Jawab Notaris}

Setiap kesepakatan yang didapat sebaiknya direalisasikan dalam kontrak atau perjanjian, agar setiap pihak paham akan hak dan kewajiban guna menghindari sengketa di kemudian hari ataupin dapat dijadikan dasar acuan untuk menyelesaikan perselisihan yang terjadi.Perjanjian yang telah dibuat akan mengikat para pihak yang mengadakannya. Pada umumnya suatu perjanjian dituangkan ke dalam tulisan atau perjanjian tertulis atau surat.

Peran notaris dalam hal ini, apabila para pihak menuangkan perjanjian tersebut dalam sebuah akta dan telah di legalisir oleh notaris dan memenuhi unsur perjanjian dan undang-undang yang berlaku sehingga akta tersebut menjadi autentik dan dapat menjadi alat bukti di pengadilan. Suatu tindakan tindakan agar dapat digolongkan pada perjanjian, maka tindakan hukum 
tersebut harus memenuhi unsur sebagai berikut :

1. Kata sepakat di antara dua ppihak atau lebih

2. Kata sepakat yang tercapai tergantung pada para pihak ;

3. Kemauan para pihak untuk timbulnya akibat hukum;

4. Untuk kepentingan yang satu atas beban pihak lain atau timbale balik;

5. Dengan mengindahkan persyaratan undang-undang ${ }^{7}$

Setelah hal tersebut diatas terpenuhi maksud dan tujuan warga negara sebagai pengguna jasa notaris disini memperoleh kepastian hukum, tanggal dan waktu dan tempat dari akta perjanjian yang dibuat di hadapan notaris, berikut adalah tanggung jawab notaris.Sesuai pasal 1 Peraturan jabatan Notaris dikemukakan bahwa Notaris adalah pejabat umum satusatunya yang berwenang untuk membuat akte otentik mengenai semua perbuatan, perjanjian, dan penetapan yang diharuskan oleh suatu peraturan umum atau oleh yang berkepentingan dikehendaki untuk dinyatakan dalam suatu akta otentik, menjamin kepastian tanggalnya, menyimpan aktanya dan memberikan grosse, salinan, dan kutipanya, semuanya sepanjang akte itu oleh suatu peraturan tidak juga ditugaskan atau dikecualikan kepada pejabat atau orang lain.

\section{Perlindungan Hukum Terhadap Jabatan}

Menurut Logemann jabatan adalah suatu lingkungan pekerjaan yang

7 Herlien Budiono, 2007, Kumpulan Tulisan Hukum Perdata di Bidang Kenotariatan, Bandung, PT Citra Aditya Bakti, hal. 267. sebanyak-banyaknya dapat dinyatakan dengan tepat dan teliti, (zoveel mogelijk nauwkeurig omsschreven). Kemudian E. Utrecht mengutip bahwa jabatan adalah (ambt) yaitu suatu lingkungan pekerjaan tetap, (kring van vaste werkzaamheden) yang diadakan dan dilakukan guna kepentingan negara (kepentingan umum $)^{8}$.

Jabatan merupakan subyek hukum, yakni pendukung hak dan kewajiban, hanya saja dalam hal ini jabatan oleh hukum tatanegara memaknai kekuasaan tidak diberikan kepada (orang/subyek hukum), tetapi kepada "Penjabat" (orang yang di kehendaki oleh jabatan) untuk menduduki jabatan, yang masa jabatannya ditentukan oleh aturan dan atau undang-undang/hukum yang mengaturnya.

Terdapat hak dan kewajiban juga tugas dan wewenang yang terkandung di dalam jabatan tersebut yang Sehingga seperti dijelaskan diatas setiap tindak-tanduk pejabat yang mengatasnamakan kepentingan jabatan/organisasi haruslah sesuai dengan aturuan dan atau undangundang.

Hukum yang berlaku mengenai jabatan terkait, sebagai payung hukum yang memberikan perlindungan hukum dikala pejabat dimaksud melanggar aturan jabatan atau jika sedang dalam masa memangku jabatannya dipersalahkan oleh negara dan atau pihak-pihak yang di dalam kepentingannya mempersalahkan pejabat tersebut.

8 E. Utrecht, 1963, Pengantar Hukum Administrasi Indonesia, Djakarta, Penerbitan dan Balai Buku Ichtiar, hal. 160. 
5. Perlindungan Hukum Terhadap Jabatan Notaris

Berikut kaitannya dengan perlindungan hukum jabatan notaris yang diatur di dalam beberapa pasal di dalam UUJN, KUHP, KUHAP, KUH Perdata yaitu : Hak Ingkar Notaris sebagai pejabat umum dalam menjalankan profesi dan jabatannya untuk memberikan pelayanan hukum kepada masyarakat, mempunyai kewajiban yang ditentukan dalam undang-undang demi tercapainya perlindungan dan kepastian hukum, antara lain:

1. Pasal 4 ayat (2) dalam alinea ke-4 memuat Sumpah Jabatan Notaris mengenai kewajiban Notaris untuk merahasiakan isi akta

2. Pasal 16 ayat (1) huruf e UUJN mengatur kewajiban notaris dalam menjalankan jabatannya

3. Pasal 54 UUJN yang mengatur mengenai grosseakta, salinan akta dan kutipan akta

4. Pasal 322 ayat (1), KUHP barang siapa dengan sengaja membuka rahasia yang wajib disimpannya karena jabatan atau pencahariannya, baik yang sekarang, maupun yang dahulu, diancam dengan pidana penjara paling lama Sembilan bulan atau denda paling banyak enam ratus rupiah $^{9}$.

5. Pasal 170 ayat (1), mereka yang karena pekerjaan, harkat martabat atau jabatannya diwajibkan menyimpan rahasia, dapat minta dibebaskan dari kewajiban untuk member keterangan sebagai saksi,

${ }^{9}$ Moeljatno, 1978, KUHP (terjemahan), pasal 322 ayat (1) Bab XVII, hal. 111. yaitu tentang hal yang dipercayakan kepada mereka ${ }^{10}$.

6. Pasal 1909 ayat (3), semua orang yang cakap untuk menjadi saksi, diharuskan member kesaksian di muka hakim. Namun dapatlah meminta dibebaskan dari kewajibannya memberikan kesaksian : segal siapa yang karena kedudukannya, pekerjaannya atau jabatannya menurut undang-undang, diwajibkan merahasiakan sesuatu, namun hanyalah semata-mata mengenai hal-hal yang pengetahuannya dipercayakan kepadanya sebagai demikian ${ }^{11}$.

Hak ingkar ini merupakan pengecualian terhadap ketentuan umum yang disebut di atas, yakni bahwa setiap pihak yang dipanggil sebagai saksi, wajib memberikan kesaksian.Istilah hak ingkar merupakan terjemahan dari (verschonningsrecht), yang artinya adalah hak untuk dibebaskan dari memberikan keterangan sebagai saksi dalam suatu perkara perdata maupun pidana atau hak ingkar adalah hak tolak atau hak minta dibebaskan untuk dapat menjadi saksi di muka pengadilan.

Dasar hak ingkar adalah jabatan kepercayaan yang memiliki peranan penting untuk menjaga kepercayaan yang diberikan para pihak penggunan jasa notaris di dalam tata tertib hukum

${ }^{10}$ Seri Publlikasi Lembaga Dokumentasi dan Informasi Hukum FHPM UNUD, 1981, Kitab Undang-Undang Acara Pidana, pasal 170 ayat (1), hal. 65 .

11 Soesilo dan Pramudji R., 2007, Kitab Undang-Undang Hukum Perdata, pasal 1909 ayat (3), Wipress, hal. 426. 
Indonesia. Apabila suatu saat seorang berada dalam suatu masalah, dapat menghubungi seorang kepercayaan untuk mendapatkan bantuan yang dibutuhkan dibidang yuridis kaitannya dalam bahasan substansi ini, dengan keyakinan bahwa akan mendapatkan nasehat-nasehat atau pemecahan masalah tanpa merugikan dirinya.

Berdasarkan uraian di atas bahwa salah satu bentuk perlindungan hukum yang diberikan oleh UUJN yaitu adanya Hak Ingkar bagi Notaris, Notaris wajib untuk merahasiakan, tidak hanya terhadap hal-hal yang dicantumkan dalam aktanya (isi akta), akan tetapi juga untuk semua yang diberitahukan atau disampaikan kepadanya selaku Notaris ataupun yang diketahuinya karena jabatannya, sekalipun itu tidak dicantumkan dalam akta. Notaris dapat mempergunakan haknya untuk mengundurkan diri sebagai saksi dengan jalan menuntut pengunaan hak ingkar.

\section{Pengertian Perlindungan Hukum}

Terhadap Jabatan Notaris

Kedudukan notaris sebagai pejabat umum merupakan suatu jabatan terhormat yang diberikan oleh negara secara atributif melalui undang-undang kepada seorang yang dipercayainya. Sebagai pejabat umum, notaris diangkat oleh menteri, berdasarkan pasal 2 UUJN. Jadi di dalam menjalankan tugasnya dengan bebas, tanpa pengaruh dari badan eksekutif dan badan lainnya dan dapat bertindak netral dan independen.

Tugas notaris adalah unutk melaksanakan sebagian fungsi publik dari negara dan bekerja untuk pelayanan kepentingan umum khususnya dalam bidang hukum perdata, walaupun notaris bukan merupakan pegawai negeri yang menerima gaji dari negara. sebagai profesi hukum yang tidak dapat dilepaskan dari keagungan hukum itu sendiri, sehingga notaris diharapkan bertindak untuk merefleksikannya di dalam pelayanannya kepada masyarakat.

Dalam hal ini notaris mendapat kuasa dari Kementerian Kehakiman untuk mengesahkan dan menyaksikan berbagai surat pejanjian, surat wasiat, akta dan sebagainya. Apa yang diperjanjikan dan dinyatakan oleh para pihak, sebagai yang dilihat atau didengar oleh notaris, terutama benar mengenai tanggal akta, tanda tangan di dalam akta, identitas yang hadir, dan tempat akta itu dibuat. ${ }^{12}$

Jabatan notaris merupakan suatu jabatan yang keberadaannya dikehendaki oleh Negara dan undangundang, hal ini dikarenakan demi terciptanya kepastian hukum bagi para pihak yang berkepentingan menggunakan jasa notaris dalam ranah hukum privat. Suatu interaksi yang baik dalam lalu lintas ranah privat dan publik haruslah merefleksikan nilainilai kepastian hukum dan keadilan.Sehingga dalam hal ini tercermin perlindungan hukum terhadap jabatan notaris tersirat didalam undang-undang.

7. Pengaturan Perlindungan Hukum Terhadap Jabatan Notaris

Berikut di jelaskan tentang pengaturan perlindungan hukum

${ }^{12}$ Ibid, hal. 7. 
jabatan notaris, yaitu pada Pasal 1 angka 6 Majelis Pengawas adalah suatu badan yang mempunyai kewenangan dan kewajiban untuk melaksanakan pembinaan dan pengawasan terhadap notaris.

Seperti kita ketahui setiap profesi jabatan tentu memiliki undang-undang sebagai paying hukum/perlindungan hukum bagi jabatan, berikut yang saya uraikan adalah bentuk-bentuk perlindungan hukum bagi terhadap jabatan notaris, diantaranya adalah :

1. Kekuatan Pembuktian Akta Autentik/Sempurna :

2. Pengawasan Kinerja Jabatan Notaris Oleh MPD :

3. Kewajiban Ingkar :

4. Hak ingkar :

\section{Majelis Pengawas Notaris}

Tujuan lain dari pengawasan terhadap notaris, bahwa notaris dihadirkan untuk melayani kepentingan masyarakat yang membutuhkan alat bukti berupa akta otentik sesuai permintaan yang bersangkutan kepada notaris, maka notaris tidak ada gunanya. Meskipun demikian tidak berarti dengan bergantian instansi yang melakukan pengawasan notaris tidak akan terjadi pelanggaran-pelanggaran yang dilakukan notaris, karena betapapun ketatnya pengawasan yang dilakuakan majelis pengawas notaris, tidak mudah untuk melakukan untuk melakukan pengawasan tersebut, hal ini terpulang kepada notaris sendiri dengan kesadaran dan penuh tanggung jawab dalam tugas jabatannya mengikuti atau berdasarkan peraturan hukum yang berlaku. ${ }^{13}$.

$$
\text { Pasal } 67 \text { ayat (1) UUJN }
$$
menentukan bahwa yang melakukan pengawasan terhadap Notaris dilakukan oleh Menteri. Dalam melaksanakan pengawasan tersebut Menteri membentuk Majeis Pengawas (Pasal 67 ayat (2) UUJN). Pasal 67 ayat (3) UUJN menentukan Majelis Pengawas tersebut terdiri dari 9 (Sembilan) orang, terdiri dari unsur :

a. Pemerintah sebanyak 3 (tiga) orang

b. Organisasi notaris sebanyak 3 (tiga) orang

c. Ahli/akedemik sebagnya 3 (tiga) orang

Dalam pasal 3 ayat (1), pasal 4 ayat (1) dan pasal 5 ayat (1) peraturan Menteri ditentukan pengusulan Anggota Majelis Pengawas. Pasal 3 ayat (1) menentukan pengusulan Anggota Majelis Pengawas Daerah (MPD) degan ketentuan:

a. Unsur pemerintah oleh Kepala Divisi Pelayanan Hukum Kantor Wilayah

b. Unsur organisasi Notaris oleh Pengurus Daerah Ikatan Notaris Indonesia

c. Unsur ahli/akademisi oleh pemimpin fakultas hukum atau perguruan tinggi setempat

Pasal 4 ayat (1) menentukan pengusulan Anggota Majelis Pengawas Wilayah (MPW) dengan ketentuan :

a. Unsur pemerintah oleh Kepala Kantor Wilayah

${ }^{13}$ Habib Adjie, 2011, Majelis Pengawas Notaris Sebagai Pejabat Tata Usaha Negara, Bandung, PT Refika Aditama, hal. 4. 
b. Unsur organisasi Notaris oleh Pengurus Wilayah Ikatan Notaris Indonesia

c. Unsur ahli/akademis oleh pemimpin fakultas hokum atau perguruan tinggi setempat

Pasal 5 ayat (1) menentukan pengusulan Anggota Majelis Pengawas Pusat

(MPP) dengan ketentuan :

a. Unsur pemerintah oleh Direktur Jendral Adminitrasi Hukum Umum

b. Unsur Organisasi Notaris oleh Pengurus Pusat Ikatan Notaris Indonesia

c. Unsur ahli/akademisi oleh dekan fakultas hukum universitas yang menyelenggarakan program magister kenotariatan

Menurut pasal 68 UUJN, bahwa Majelis Pengawas Notaris, terdiri atas

a. Majelis Pengawas Daerah

b. Majelis Pengawas Wilayah

c. Majelis Pengawas Pusat

\section{Struktur Majelis Pangawas Notaris}

1. Majelis Pengawas Daerah (MPD) Wewenang MPD diatur dalam UUJN, Peraturan Menteri Hukum dan Hak asasi Manusia Republik Indonesia Nomor M.02.PR.08.10 Tahun 2004, dan Keputusan Menteri Hukum dan Hak asasi Manusia Republik Indonesia Nomor M.39PW.07.10 Tahun 2004. Dalam pasal 66 UUJN diatur mengenai wewenang MPD.

2. Wewenang MPW di samping diatur dalam UUJN, juga diatur dalam Peraturan Menteri Hukum dan Hak Asasi Manusia Republik Indonesia Nomor M.02.PR.08.10 Tahun 2004, dan Keputusan Menteri
Hukum dan Hak Asasi Manusia Republik Indonesia Nomor m.39PW.07.10 Tahun 2004. Dalam pasal 73 ayat (1) UUJN diatur mengenai wewenang MPW.

3. Wewenang MPP di samping diatur dalam UUJN, juga diatur dalam Peraturan Menteri Hukum dan Hak Asasi Manusia Republik Indonesia Nomor M.02.PR.08.10 Tahun 2004, dan Keputusan Menteri Hukum dan Hak Asasi Manusia Republik Indonesia Nomor m.39PW.07.10 Tahun 2004. Dalam pasal 77 UUJN diatur mengenai wewenang MPW.

10. Tugas dan Wewenang Majelis Pengawas Notaris Daerah

Berangkat dari pasal 66 UUJN diatur mengenai tugas dan wewenang Majelis Pengawas Notaris Daerah diataranya :

1. Untuk kepentingan proses peradilan, penyidik, penuntut umum, atau hakim dengan persetujuan MPD berwenang :

a. Mengambil fotokopi minuta akta dan surat-surat yang diletakkan pada minuta akta atau protokol notaris dalam penyimpanan notaris

b. Memanggil notaris untuk hadir dalam pemeriksaan yang berkaitan dengan akta yang dibuatnya atau protokol notaris yang berada dalam penyimpanan notaris.

2. Pengambilan fotokopi minuta akata atau surat-surat sebagaimana dimaksud pada ayat (1) huruf a dibuat berita acara penyerahan. 
Hasil dari pemeriksaan yang dilakuakan oleh MPD berupa surat keputusan merupakan suatu penetapan tertulis. Surat keputusan tersebut bersifat konkret, individual, final dan menimbulkan akibat hukum. Arti dari surat keputusan tersebut adalah berasal dari obyek akta tertentu yang diperiksa MPD dibuat oleh notaris bersangkutan, dan keputusan tersebut tidak ditujukan untuk umum, tetapi kepada notaris bersangkutan dan bersifat final yang tidak memerlukan persetujuan dari pihak lain atau institusi atasannya yang hal ini merupakan pelaksanaan dari pasal 66 UUJN.

\section{Perlindungan Hukum Terhadap Jabatan} Notaris Oleh Majelis Pengawas Notaris

Hasil dari pemeriksaan yang
dilakuakan oleh MPD berupa surat
keputusan merupakan suatu penetapan tertulis. Surat keputusan tersebut bersifat konkret, individual, final dan menimbulkan akibat hukum. Arti dari surat keputusan tersebut adalah berasal dari obyek akta tertentu yang diperiksa MPD dibuat oleh notaris bersangkutan, dan keputusan tersebut tidak ditujukan untuk umum, tetapi kepada notaris bersangkutan dan bersifat final yang tidak memerlukan persetujuan dari pihak lain atau institusi atasannya yang hal ini merupakan pelaksanaan dari pasal 66 UUJN.

12. Sifat dan Kekuatan Hukum Putusan MKRI

Suatu putusan peradilan merupakan perbuatan hukum sebagai pejabat negara berwenang yang diucapkan dalam sidang terbuka untuk umum dan dibuat secara tertulis untuk mengakhiri sengketa yang dihadapkan para pihak kepadanya. Dengan kata lain, putusan pengadilan adalah refleksi dari pernyataan hakim sebagai pejabat negara yang diberi wewenang oleh UUD 1945 atau undang-undang untuk mengakhiri atau menyelesaikan suatu sengketa yang timbul dalam

kehidupan bermasyarakat dan bernegara. ${ }^{14}$

Putusan Mahkamah Konstitusi bersifat final dan mengikat. Menurut Sri Soemantri, putusan yang bersifat final harus bersifat mengikat dan tidak bisa dianulir oleh lembaga apapun. Dalam bahasa Inggris, pengertian yuridis final dan mengikat itu selalu bersatu, yaitu final and binding. Dengan demikian, jika bersifat final harus diikuti dengan mengikat sehingga sah memiliki kepastian hukum

Kata bersifat final itu implisit telah mengikat dan tidak bisa dianulir sehingga tidak perlu ditambahi dengan kata-kata mengikat. Menurut Indroharto, kata final, akibat hukum yang ditimbulkan serta dimaksudkan dengan mengeluarkan penetapan tertulis itu harus benar-benar sudah merupakan akibat hukum yang definitif. $^{15}$

${ }^{14}$ Iriyanto A. BasoEnce, Negara Hukum dan Hak Uji Konstitusionalitas Mahkamah Konstitusi, PT. Alumni, hal.190.

${ }^{15}$ Abdul Rasyid Thalib, 2006, Wewenang Mahkamah Konstitusi dan Implikasinya Dalam Sistem Ketatanegaraan Republik Indonesia, 
13. Akibat Hukum Putusan MKRI Nomor:

49/ PUU-X/ 2012 Terhadap

Perlindungan Hukum Jabatan Notaris

Pada tanggal 31 Mei 2013 Firdhonal mengatakan berkenaan dengan putusan MK dengan nomor perkara 49/PUU-X/2012 yang dibacakan amar putusannya pada tanggal 28 Mei 2013." Putusan ini harus kita hormati, hormati dan junjung tinggi karena setiap putusan MK bersifat Final dan mengikat, ada efek besar yang ditimbulkan oleh putusan ini yaitu notaris akan berada dalam posisi yang sangat dilematis".

Penulis berpendapat bahwa Putusan dari MKRI tersebut dapat berakibat pada lemahnya perlindungan hukum terhadap notaris dalam hal akta yang dibuatnya, terutama pada putusan yang mencabut Pasal 66 tentang kewenangan MPD yang menyebabkan akta yang dibuat notaris dapat diperiksa oleh pihak berwajib tanpa melalui persetujuan MPD. Sedangkan Notaris sebagai pejabat umum berpotensi melanggar KUHP apabila membocorkan rahasia negara dengan ancaman pidana penjara paling lama Sembilan bulan atau pidana denda paling banyak Sembilan ribu rupiah. Dibagian lain KUHP juga mengisyaratkan bahwa notaris dibebaskan dari kewajiban untuk memberi keterangan sebagai saksi, yaitu tentang hal yang dipercayakan kepada mereka. Hal ini berarti Notaris dalam melaksanakan fungsi dan jabatannya harus merahasiakan isi akta yang dibuatnya.

\section{SIMPULAN DAN SARAN}

\section{A. Simpulan}

Berdasarkan uraian dalam pembahasan bab-bab sebelumnya, maka dapat disimpulkan beberapa simpulan. Simpulan-simpulan tersebut antara lain:

1 Putusan Mahkamah Konstitusi Republik

Indonesia Nomor : 49/PUU-X/2012,

PT. Citra Aditya Bakti, Bandung, hal.491. mencabut perlindungan hukum rahasia jabatan notaris melalui pasal 66 dengan frasa "dengan persetujuan MPD" di hilangkan adalah melanggar rahasia jabatan negara. Upaya hukum dari putusan MKRI tersebut mengakibatkan lahirnya UndangUndang Nomor 2 Tahun 2014 tentang Perubahan Undang-undang Nomor 30 Tahun 2004 Tentang Jabatan Notaris. Termaktub juga di dalam ketentuan tersebut mengenai bentuk perlindungan hukum bagi jabatan notaris, diantaranya: kekuatan pembuktian akta autentik atau sempurna, pengawasan kinerja jabatan Notaris Oleh Majelis Kehormatan Notaris, kewajiban Ingkar dan hak ingkar notaris.

2 Putusan yang mencabut Pasal 66 tentang kewenangan MPD yang menyebabkan akta yang dibuat notaris dapat diperiksa oleh pihak berwajib tanpa melalui persetujuan MPD. Sedangkan Notaris sebagai pejabat umum berpotensi melanggar KUHP apabila membocorkan rahasia negara dengan ancaman pidana penjara paling lama Sembilan bulan atau pidana denda paling banyak Sembilan ribu rupiah. Dibagian lain KUHP juga mengisyaratkan bahwa notaris dibebaskan dari kewajiban untuk memberi keterangan sebagai saksi, yaitu tentang hal yang dipercayakan kepada mereka. Hal ini berarti Notaris dalam melaksanakan fungsi dan jabatannya harus merahasiakan isi akta yang dibuatnya.

\section{B. Saran}

Berdasarkan simpulan tersebut di atas maka ada beberapa saran yang dapat disampaikan. Saran-saran tersebut adalah sebagai berikut:

1. Kepada aparat penegak hukum dalam hal ini kepolisian, kejaksaan, dan kehakiman Republik Indonesia agar dalam menerapkan putusan MKRI tersebut, 
memperhatikan pula kewenangan yang dimiliki oleh notaris sebagai pejabat umum yang wajib menjaga kerahasiaan dari akta otentik yang dibuatnya.

2. Bagi Para Notaris agar menyadari bahwa putusan yang menghilangkan kewenangan MPD tidak sepenuhnya melemahkan posisi notaris sebagai pejabat umum, karena KUHP mengisyaratkan bahwa notaris wajib merahasiakan dokumen negara termasuk di dalamnya akta otentik yang diterbitkannya. Sepanjang dalam melaksanakan tugasnya tidak bertentangan dengan Pasal 1320 KUHPerdata, Pasal 1338 KUHPerdata dan UUJN, maka hak ingkar ini dapat digunakan bilamana diperlukan.

\section{DAFTAR PUSTAKA}

A. BasoEnce, Iriyanto, Negara Hukum dan Hak Uji Konstitusionalitas Mahkamah Konstitusi, PT. Alumni.

Ali, Achmad, 2009, Menguak Teori (Legal Theory) dan Teori peradilan (Judicial Prudence) Termasuk Interprestasi Undang-Undang( Legisprudence), Prenada Media Group, Jakarta.

Budiono, Herlien, 2007, Kumpulan Tulisan Hukum Perdata di Bidang Kenotariatan, Bandung, PT Citra Aditya Bakti.

Dewi, Santia dan R.M. Fauwas Diradja, 2011, Panduan Teori dan Praktik Notaris, Yogyakarta, Penerbit Pustaka Yustisia.

Habib Adjie, 2011, Majelis Pengawas Notaris Sebagai Pejabat Tata Usaha Negara, Bandung, PT Refika Aditama.

Hadjon dkk, 2002, Pengantar Administrasi Negara, Penerbit Gajah Mada University, Yogyakarta.

Meuwissen, 2007, Tentang Pengembanan Hukum, Ilmu Hukum, Teori Hukum dan Filsafat Hukum, alih bahasa B. Arieff Sidharta, Refika Aditama, Bandung.

Rasyid Thalib, Abdul, 2006, Wewenang Mahkamah Konstitusi dan Implikasinya Dalam Sistem Ketatanegaraan Republik Indonesia, PT. Citra Aditya Bakti, Bandung.

Seri Publlikasi Lembaga Dokumentasi dan Informasi Hukum FHPM UNUD, 1981, Kitab UndangUndang Acara Pidana, pasal 170 ayat (1)

Soesilo dan Pramudji R., 2007, Kitab Undang-Undang Hukum Perdata, pasal 1909 ayat (3), Wipress.

Utrecht, E.,1963, Pengantar Hukum Administrasi Indonesia, Djakarta, Penerbitan dan Balai Buku Ichtiar

$$
* * * * *
$$

